\title{
The Use of Chemical and Physical Properties for Characterization of Strontium Distribution Coefficients at the Idaho National Engineering and Environmental Laboratory, Idaho
}

By Jeffrey J. Rosentreter, Reinaldo Nieves, and John Kalivas of Idaho State University and Joseph P. Rousseau and Roy C. Bartholomay of the U.S. Geological Survey

U.S. GEOLOGICAL SURVEY

Water-Resources Investigations Report 99-4123

Prepared in cooperation with the

U.S. DEPARTMENT OF ENERGY
BECEIVET

NOV 012000

OSTI

Idaho Falls, Idaho

June 1999 


\title{
U.S. DEPARTMENT OF THE INTERIOR \\ BRUCE BABBITT, Secretary
}

\author{
U.S. GEOLOGICAL SURVEY
}

Charles G. Groat, Director

Any use of trade, product, or firm names in this publication is for descriptive purposes only and does not constitute endorsement by the U.S. Government.

For additional information write to:

\section{U.S. Geological Survey}

INEEL, MS 1160

P.O. Box 2230

Idaho Falls, ID 83403-2230
Copies of this report can be purchased from:

U.S. Geological Survey

Information Services

Box 25286, Federal Center

Denver, CO 80225 


\section{- DISCLAIMER}

This report was prepared as an account of work sponsored by an agency of the United States Government. Neither the United States Government nor any agency thereof, nor any of their employees, make any warranty, express or implied, or assumes any legal liability or responsibility for the accuracy, completeness, or usefulness of any information, apparatus, product, or process disclosed, or represents that its use would not infringe privately owned rights. Reference herein to any specific commercial product, process, or service by trade name, trademark, manufacturer, or otherwise does not necessarily constitute or imply its endorsement, recommendation, or favoring by the United States Government or any agency thereof. The views and opinions of authors expressed herein do not necessarily state or reflect those of the United States Government or any agency thereof. 


\section{DISCLAIMER}

Portions of this document may be illegible in electronic image products. Images are produced from the best available original document. 


\section{CONTENTS}

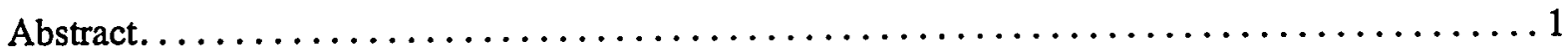

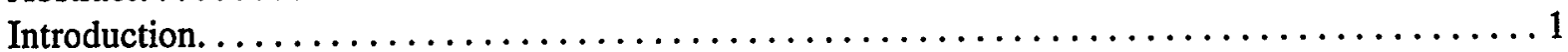

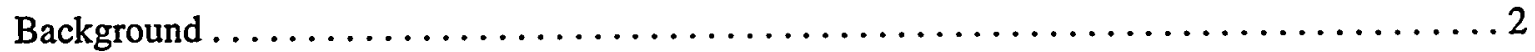

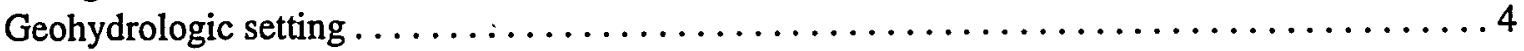



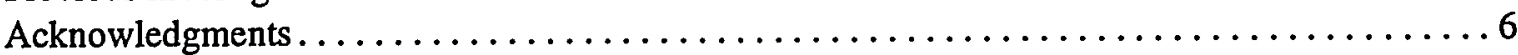

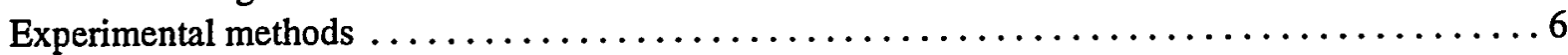

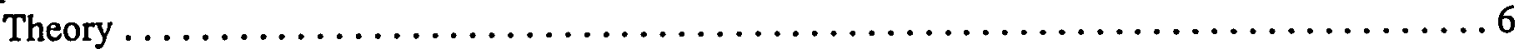

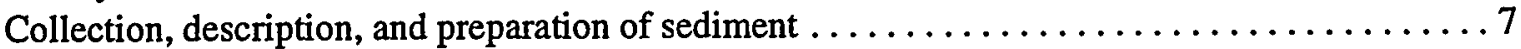

Methodology and determination of partition and solution variables $\ldots \ldots \ldots \ldots \ldots \ldots \ldots 7$

Derivation of the strontium distribution coefficient using the linear isotherm model . . . . . . . . 9

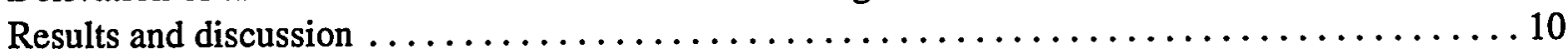

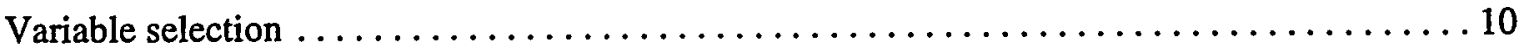

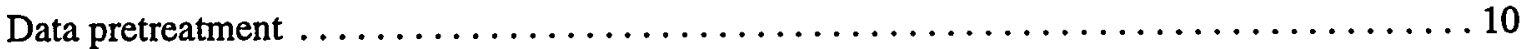

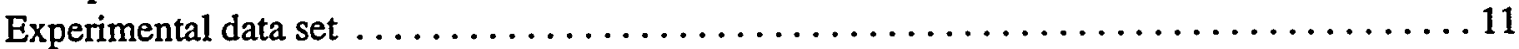

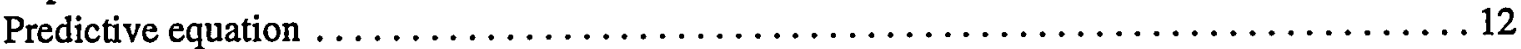

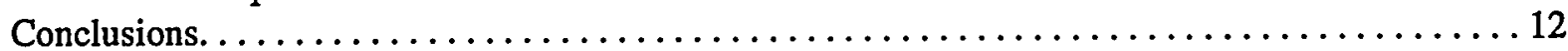

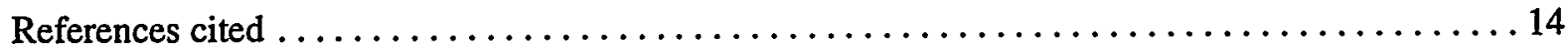

\section{FIGURES}

Figure 1. Map showing the location of the Idaho National Engineering and Environmental



2. Map showing the location of selected waste disposal sites at the Idaho Nuclear Technology and Engineering Center and Test Reactor Area, Idaho National Engineering and Environmental Laboratory . . . . . . . . . . . . . . . . . . 5

3. Map showing the location of sites where surficial-sediment samples were collected, Idaho National Engineering and Environmental Laboratory $\ldots \ldots \ldots \ldots \ldots \ldots . \ldots$

4. Graph showing predicted strontium distribution coefficients $\left(\mathrm{Sr} \mathrm{K}_{\mathrm{d}} \mathrm{s}\right)$ with respect to observed $\mathrm{Sr} \mathrm{K}_{\mathrm{d}} \mathrm{s}$ for the data set without grain-size distributions using two partial least- square factors with the four variables $\mathrm{MnO}, \mu \mathrm{S}, \mathrm{pH}$, and $\mathrm{SA} \ldots \ldots \ldots \ldots \ldots 13$

\section{TABLES}

Table 1. Sample depth, texture, and distribution coefficients of surficial-sediment samples from the Idaho National Engineering and Environmental Laboratory. . . . . . . . . . . 17

2. Grain-size distribution of surficial-sediment samples from the Idaho National Engineering and Environmental Laboratory $\ldots \ldots \ldots \ldots \ldots \ldots \ldots \ldots \ldots \ldots \ldots \ldots \ldots$

3. Bulk mineralogy of surficial-sediment samples from the Idaho National Engineering

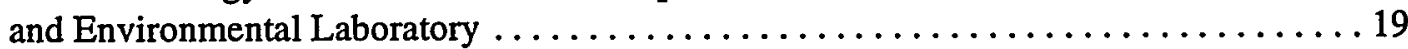

4. Whole-rock analysis of selected major, minor, and trace elements in surficial-sediment samples from the Idaho National Engineering and Environmental Laboratory . . . . . . 20

5. Brunauer-Emmett-Teller surface area of surficial-sediment samples from the Idaho National Engineering and Environmental Laboratory. . . . . . . . . . . . . . 21 
6. Concentrations of alkalinity, calcium, magnesium, potassium, silica, sodium, strontium, and $\mathrm{pH}$ in the two batches of synthesized aqueous solutions used in the

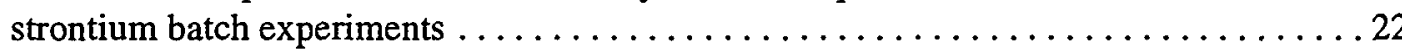

7. Chemical and physical variables describing the aqueous solution and sediments measured in each experimental distribution coefficient determination

8. Results for variable selection on strontium distribution coefficient values of surficial sediments using partial least squares and all possible variables . . . . . . . 24

9. Results for variable selection on strontium distribution coefficient values of surficial sediments using partial least squares and all variables except grain-size distribution.

\section{CONVERSION FACTORS AND ABBREVIATIONS FOR UNITS}

$\begin{array}{lcl}\text { Multiply } & \underline{\text { By }} & \text { To obtain } \\ \text { gram }(\mathrm{g}) & .03527 & \text { ounce } \\ \text { kilogram }(\mathrm{kg}) & 2.205 & \text { pound } \\ \text { kilometer }(\mathrm{km}) & .6215 & \text { mile } \\ \text { square kilometer }\left(\mathrm{km}^{2}\right) & .3861 & \text { square mile } \\ \text { meter }(\mathrm{m}) & 3.281 & \text { foot } \\ \text { millimeter }(\mathrm{mm}) & .0394 & \text { inch } \\ \text { becquerel per liter }(\mathrm{Bq} / \mathrm{L}) & 27 & \text { picocurie per liter }(\mathrm{pCi} / \mathrm{L}) \\ \text { terra becquerel }(\mathrm{TBq}) & 27 & \text { curie }\end{array}$

For temperature, degrees Celsius $\left({ }^{\circ} \mathrm{C}\right)$ can be converted to degrees Fahrenheit $\left({ }^{\circ} \mathrm{F}\right)$ by using the formula ${ }^{\circ} \mathrm{F}=(1.8)\left({ }^{\circ} \mathrm{C}\right)+32$.

Abbreviated units used in report: $\mathrm{K}_{\mathrm{d}}$ (distribution coefficient), $\mathrm{mg} / \mathrm{L}$ (milligrams per liter), $\mathrm{mL}$ (milliliter), $\mathrm{mL} / \mathrm{g}$ (milliliters per gram), $\mathrm{mg} / \mathrm{kg}$ (milligrams per kilogram), $\mu \mathrm{s} / \mathrm{cm}$ (microsiemens per centimeter) at $25^{\circ} \mathrm{C}, \mathrm{m}^{2} / \mathrm{g}$ (meters squared per gram). 


\title{
The Use of Chemical and Physical Properties for Characterization of Strontium Distribution Coefficients at the Idaho National Engineering and Environmental Laboratory, Idaho
}

\author{
By Jeffrey J. Rosentreter, Reinaldo Nieves, John Kalivas, Joseph P. Rousseau, and Roy \\ C. Bartholomay
}

\begin{abstract}
The U.S. Geological Survey and Idaho State University, in cooperation with the U.S. Department of Energy, conducted a study to determine strontium distribution coefficients $\left(K_{d} s\right)$ of surficial sediments at the Idaho National Engineering and Environmental Laboratory (INEEL). Batch experimental techniques were used to determine experimental $\mathrm{K}_{\mathrm{d}} \mathrm{s}$ of 20 surficial-sediment samples from the INEEL. The $K_{d} s$ describe the distribution of a solute between the solution and solid phase. $\mathrm{K}_{\mathrm{d}} \mathrm{S}$ of the 20 surficial-sediment samples ranged from 36 to 275 milliliters per gram. Many chemical and physical properties of both the synthesized aqueous solution and sediments used in the experiments also were determined. The following solution properties were determined: initial and equilibrium concentrations of calcium, magnesium, and strontium; $\mathrm{pH}$ and specific conductance; and initial concentrations of potassium and sodium. Sediment properties determined were grain-size distribution, mineralogy, whole-rock major oxide, strontium and barium concentrations, and Brunauer-Emmett-Teller surface area. Multivariate-regression techniques were used to identify which of these variables or set of variables could best predict the strontium $\mathrm{K}_{d}$ values. Partial leastsquares regression was used to fit these data to an empirical model that could be used to predict strontium $\mathrm{K}_{\mathrm{d}} \mathrm{s}$ of surficial sediments at the INEEL. The best-fit model was obtained using a four-variable data set consisting of surface area, manganese oxide concentration, specific conductance, and $\mathrm{pH}$. Application of the model to an independent split of the data resulted in an average relative error of
\end{abstract}

prediction of 20 percent and a correlation coefficient of 0.921 between predicted and observed strontium $\mathrm{K}_{\mathrm{d}} \mathrm{s}$. Chemical and physical characteristics of the solution and sediment that could successfully predict the $K_{d}$ values were identified. Prediction variable selection was limited to variables which are either easily determined or have available tabulated characteristics. The selection criterion could circumvent the need for time- and labor-intensive laboratory experiments and provide an alternate faster method for estimating strontium $\mathrm{K}_{\mathrm{d}} \mathrm{s}$.

\section{INTRODUCTION}

The fate and transport of waste constituents in an aquifer are dependent on chemical and physical processes that govern the distribution of these constituents between the solid, geologic, stationary phase and an aqueous, mobile phase. This distribution often is quantified by an empirically determined parameter called the distribution coefficient $\left(\mathrm{K}_{\mathrm{d}}\right)$. $\mathrm{K}_{\mathrm{d}} \mathrm{S}$ can be used to summarize the net chemical factors that affect transport efficiency of ground-water constituents. Many transport models for radionuclides use $\mathrm{K}_{\mathrm{d}} \mathrm{s}$ to predict the extent to which the migration of the constituent will be lessened relative to the mean ground-water velocity (Bohn, 1985, Sposito, 1989, Fetter, 1993).

The U.S. Geological Survey (USGS) and Idaho State University, in cooperation with the U.S. Department of Energy (DOE), are conducting studies to determine geochemical properties affecting strontium (Sr) transport in surficial sediment at the Idaho National Engineering and Envi- 
ronmental Laboratory (INEEL), Idaho. Specifically, these studies focus on chemical constituents in wastewater discharged through the unsaturated zone and into the Snake River Plain aquifer at the INEEL. Study objectives include assessing the variability of $\mathrm{Sr} \mathrm{K}_{\mathrm{d}} \mathrm{S}$ of surficial sediments at the INEEL and identifying chemical and physical properties of the solution and sediments that can account for the variability. Understanding how different chemical and physical properties of sediment and ground water affect $\mathrm{Sr}$ sorption will allow better prediction of the rate of $\mathrm{Sr}$ transport, which will, in turn, aid in the prediction of the behavior of the strontium- $90\left({ }^{90} \mathrm{Sr}\right)$ that has been disposed of at the INEEL.

This report presents the results of a study to predict the variability of $\mathrm{Sr} \mathrm{K}_{\mathrm{d}} \mathrm{S}$ of 20 surficialsediment samples collected from selected sites at the INEEL in terms of selected chemical and physical properties of the solution and sediments. The surficial sediments were examined because pond wastewater containing ${ }^{90} \mathrm{Sr}$ interacts with the sediment before infiltrating to the aquifer. Strontium $\mathrm{K}_{\mathrm{d}} \mathrm{s}$ of the 20 surficial-sediment samples were determined using a synthesized aqueous solution and batch experimental techniques. Solution properties determined were initial and equilibrium concentrations of calcium, magnesium, and strontium; $\mathrm{pH}$ and specific conductance; and initial concentrations of potassium and sodium. Sediment properties determined were grain-size distribution, bulk mineralogy, whole-rock major oxide, strontium and barium concentrations, and BrunauerEmmett-Teller (BET) surface area. Using these chemical and physical properties, variable selection, based on multivariate regression techniques, was used to identify those properties that best predict the experimentally determined $K_{d}$ s. Additionally, variable selection was used to eliminate variables that would be difficult to obtain, either from field measurements or from standard archived information.

\section{Background}

The INEEL comprises $2,300 \mathrm{~km}^{2}$ of the eastern Snake River Plain in southeastern Idaho (fig.1). The INEEL was established in 1949 by the U.S. Atomic Energy Commission (now known as DOE) for the development of peacetime atomic-energy applications such as nuclear-safety research, defense programs, and advanced energy concepts. More than 50 nuclear reactors have been operated at the INEEL since its inception. Facilities at the INEEL also are used to store nuclear waste, such as spent fuel rods from the U.S. Navy's nuclear fleet and other DOE sites, and wastes generated on site.

Aqueous chemical and radiochemical wastes, including ${ }^{90} \mathrm{Sr}$, have been discharged to wastedisposal ponds and disposal wells at the INEEL since 1952. Since 1983, most of the wastewater has been discharged to unlined infiltration ponds. Some chemical constituents from wastewater may enter the aquifer indirectly following percolation from the waste-disposal ponds through sediments in the unsaturated zone (Pittman and others, 1988). Disposal of radioactive wastewater to the Test Reactor Area (TRA) radioactive-waste ponds ceased in August 1993 and the ponds were remediated (Eddie Chew, U.S. Department of Energy, written commun., 1995). Radioactive wastewater at the TRA now is discharged to two lined evaporation ponds. Disposal of radioactive wastewater to the Idaho Nuclear Technology and Engineering Center (INTEC) (formerly the Idaho Chemical Processing Plant) disposal well was discontinued in 1984, and wastewater has been discharged to two unlined infiltration ponds since 1984.

Strontium-90 is a radionuclide produced by the fission of uranium, has a half-life of 28.8 years, and decays through beta emission (Eisenbud, 1973, p. 83-97). The global deposition of ${ }^{90} \mathrm{Sr}$ is well documented (Eisenbud, 1973, p. 320-331). This radionuclide is present in ground water and was introduced to the environment from fallout of nuclear explosions and as a result of the wastedisposal practices used in the nuclear industry. Because of its tendency to concentrate uniformly throughout mineral bone tissues, ${ }^{90} \mathrm{Sr}$ is a health hazard. The maximum contaminant level for drinking water is about $0.3 \mathrm{~Bq} / \mathrm{L}$ (U.S. Environmental Protection Agency, 1997, p. 296).

Approximately $5.6 \mathrm{TBq}$ of ${ }^{90} \mathrm{Sr}$ was discharged at the INEEL from the early 1950 s to 1995 , primarily at the INTEC and TRA facilities (Bartholomay 


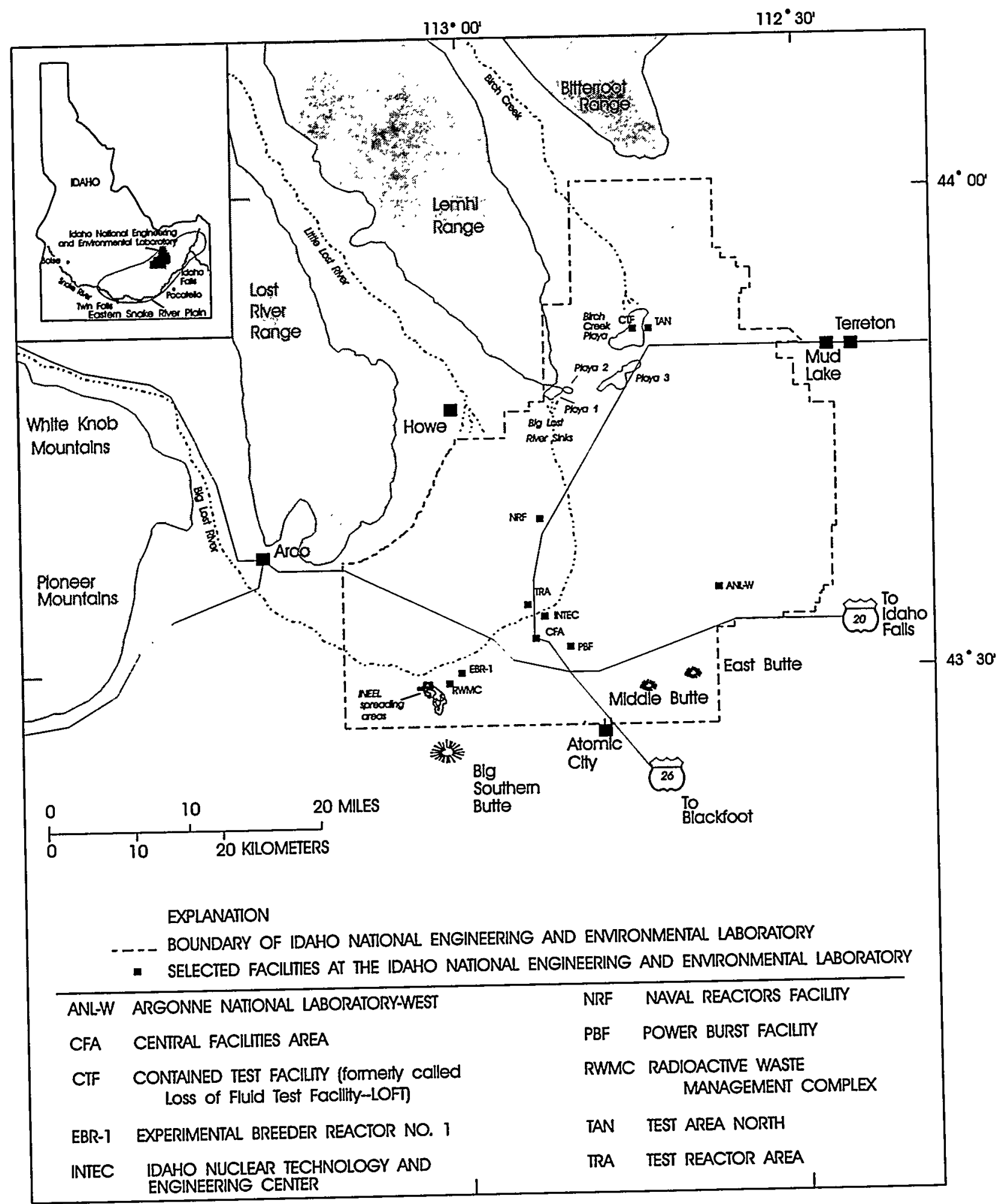

Figure 1. Location of the Idaho National Engineering and Environmental Laboratory and selected facilities. 
and others, 1997, p. 30). Documented disposals include:

- $1.2 \mathrm{TBq}$ of ${ }^{90} \mathrm{Sr}$ discharged into a pit at the INTEC during 1962-63 (Robertson and others, 1974, p. 119)

- $0.9 \mathrm{TBq}$ of ${ }^{90} \mathrm{Sr}$ discharged to a disposal well and infiltration ponds at the INTEC (fig. 2) during 1952-95, of which approximately $0.02 \mathrm{TBq}$ was discharged to the waste-disposal ponds (Bartholomay and others, 1995, p. 26; Bartholomay and others, 1997, p. 30).

- $3.4 \mathrm{TBq}$ of ${ }^{90} \mathrm{Sr}$ discharged to waste-disposal ponds at the TRA (fig. 2) during 1952-95 (Bartholomay and others, 1997, p. 30).

Concentrations of ${ }^{90} \mathrm{Sr}$ in perched ground water beneath the INTEC ranged from 0 to $0.63 \pm 0.07$ $\mathrm{Bq} / \mathrm{L}$ during 1991 through 1995 . Concentrations of ${ }^{90} \mathrm{Sr}$ in perched ground water beneath the TRA ranged from 0 to $5.3 \pm 0.2 \mathrm{~Bq} / \mathrm{L}$ during the same period (Bartholomay, 1998, p. 24). Disposal of ${ }^{90} \mathrm{Sr}$ has resulted in a $10 \mathrm{~km}^{2}$ plume within the eastern Snake River Plain aquifer beneath the INTEC (Bartholomay and others, 1997, p. 33) where concentrations are larger than $0.3 \mathrm{~Bq} / \mathrm{L}$. Concentrations of ${ }^{90} \mathrm{Sr}$ in water from wells completed in the Snake River Plain aquifer were as large as $2.8 \pm 0.1$ $\mathrm{Bq} / \mathrm{L}$ in 1995 (Bartholomay and others, 1997, p. 30). Strontium-90 has not been detected within the eastern Snake River Plain aquifer beneath the TRA. This can, in part, be explained by the exclusive use of waste-disposal ponds rather than the disposal well at this facility for radioactive-wastewater disposal. Sorption processes in the unsaturated and perched water zones beneath the wastedisposal ponds likely have lessened ${ }^{90} \mathrm{Sr}$ migration at the TRA. In addition, stratigraphy beneath the TRA is different from that beneath the INTEC (Anderson, 1991, p. 22-28).

\section{Geohydrologic Setting}

The eastern Snake River Plain is a northeasttrending structural basin about $320 \mathrm{~km}$ long and 80 to $110 \mathrm{~km}$ wide. The plain is underlain by a layered sequence of basaltic rocks and cinder beds intercalated with alluvial and lakebed deposits. Individual layers of basalt range from 3 to $15 \mathrm{~m}$ in thickness, although the average thickness may be from 6 to $8 \mathrm{~m}$ (Mundorf and others, 1964, p. 143). The sedimentary deposits consist mainly of lenticular beds of sand, silt, and clay, and lesser amounts of gravel. Locally, rhyolitic rocks and tuffs are exposed at the land surface or occur at depth. The basaltic rocks and intercalated sedimentary deposits combine to form the framework for the Snake River Plain aquifer system, which is the main source of ground water on the plain. The depth to water in the aquifer system ranges from about $60 \mathrm{~m}$ below land surface in the northern part of the INEEL to more than $275 \mathrm{~m}$ in the southern part (Bartholomay and others, 1997 , p. 20). The general direction of ground-water flow at these sites is from the northeast to the southwest. The INEEL obtains its entire water supply from the Snake River Plain aquifer.

\section{Previous Investigations}

Strontium $\mathrm{K}_{\mathrm{d}} \mathrm{s}$ of sediment collected from the INEEL have been reported by Hawkins and Short (1965); Schmalz (1972); Del Debbio and Thomas (1989); Newman and others (1996); Bunde and others (1997); Hemming and others (1997); Liszewski and others (1997); Bunde and others (1998); Liszewski, Bunde, and others (1998); and Liszewski, Rosentreter, and others (1998). Strontium $\mathrm{K}_{d} \mathrm{~s}$ of sediment from other nuclear facilities in the United States and Canada have been reported by Patterson and Spoel (1981), Jackson and Inch (1983), and Kipp and others (1986). Many researchers have studied $\mathrm{Sr}_{\mathrm{d}} \mathrm{s}$ and the factors that affect them. Some researchers have indicated that cation exchange with calcium and magnesium ions has a large effect on $\mathrm{Sr} \mathrm{K}_{\mathrm{d}}$ s (Qingzhong and Guangyu, 1989; Park and others, 1992; and Bunde and others, 1997). Other researchers, such as Inch and Killey (1987) and Tadao and Tadatoshi (1988), have found that $\mathrm{Sr} \mathrm{K}_{\mathrm{d}} \mathrm{S}$ are strongly correlated with sedimentary surface area. Furthermore, researchers have indicated that pH (Kenna, 1980; Sibley and others, 1982; and Qingzhong and Guangyu, 1989), clay content (Tadao and Tadatoshi, 1988), and salt concentrations (Rafferty and others, 1981) all have an effect on $\mathrm{Sr} \mathrm{K}_{\mathrm{d}} \mathrm{s}$.

Two different approaches have been used in previous efforts to predict sorptive behavior of ${ }^{90} \mathrm{Sr}$. In one approach, surface-site models based on 


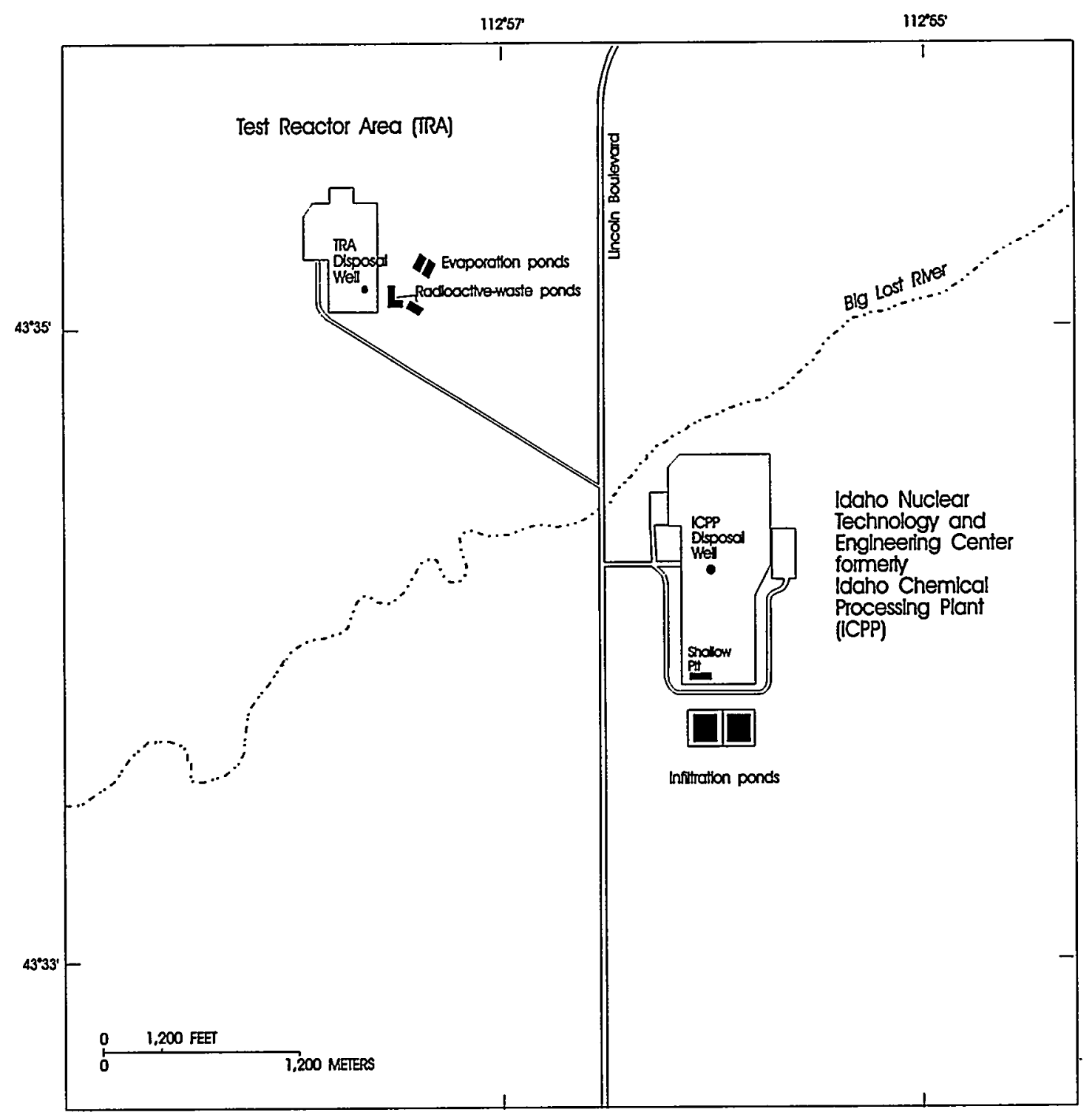

Figure 2. Location of selected waste-disposal sites at the Idaho Nuclear Technology and Engineering Center and Test Reactor Area, Idaho National Engineering and Environmental Laboratory. 
simple and complex chemical binding theory were used to predict the behavior of many different binding sites on the geologic material (Robertson and Leckie, 1991; Schnoor, 1996). In the second approach, bulk-characteristic correlations of either the solid or aqueous phase, or both, were used to predict the sorptive characteristics of a system (Robertson and Lechie, 1991; Rosentreter and others, 1997). Although both approaches have merit and applications, the latter approach is examined in this report.

\section{Acknowledgments}

The authors gratefully acknowledge the assistance and cooperation provided by Idaho State University. Special thanks go to Dr. Dennis Strommen of the Department of Chemistry for providing laboratory space. The authors are grateful to Dr. Rene Rodriguez of Idaho State University and Michael G. Rupert of the USGS for technical review of the manuscript. The authors also thank the Camille and Henry Dreyfus Foundation for its support.

\section{EXPERIMENTAL METHODS}

\section{Theory}

This report investigates which variables from the INEEL surficial-sediment data set are good predictors for $\mathrm{Sr} \mathrm{K}_{d}$ by use of a multivariate-regression method (Johnson and Wichern, 1988; Beebe and others, 1998). Numerous multivariate approaches exist: including least-squares, principal-component regression, partial least-squares (PLS) and others. The method used in this study was PLS. Regardless of the method, the data are arrayed for a linear model as

$$
\mathrm{k}=\mathrm{Xb}+\mathrm{e} \text {, }
$$

where k represents the $m \times 1$ vector of the dependent variable ( $\left(\mathrm{Sr}_{\mathrm{d}} \mathrm{s}\right)$ for $m$ samples, $\mathrm{X}$ denotes the $m \times p$ matrix of $p$ variables measured for $m$ samples, $\mathrm{b}$ is a $p \times 1$ regression vector and e symbolizes the $p \times 1$ vector of errors. For this study, $m$ has a size of 240 when individual replicates are considered and $p$ equals 54 .
Before a linear model can be developed by a multivariate-regression method for prediction purposes, a calibration step first must be performed. Mathematically, calibration consists of computing

$$
\hat{b}=X^{+} \times k \text {, }
$$

where $\hat{b}$ is the estimate of the regression vector and + denotes a generalized inverse of the matrix. A dependent-variable value is predicted by calculating

$$
k_{u n k}=\mathrm{x}_{u n k}^{T} \hat{\mathrm{b}}
$$

\section{with $T$ symbolizing transpose.}

Variable selection is a relatively common problem in studying complex environmental and geochemical processes. Because the mechanisms influencing $\mathrm{Sr} \mathrm{K}_{\mathrm{d}} \mathrm{S}$ are not well understood, a relatively large number of variables were selected so that a subset of variables that were good predictors for $\mathrm{Sr} \mathrm{K}_{\mathrm{d}}$ could be identified. Using a small set of variables has two important advantages: (1) reducing costs of study, and (2) minimizing the undesired effects of collinearity in multivariate regression. Multivariate-regression modeling methods can produce poor predictions because variables with a high degree of collinearity can increase prediction error. Many of the variables used in this study show a high degree of correlation. For example, the concentration of calcium at equilibrium with the aqueous phase in a batch experiment depends on the amount of calcium present in the sediment. Because the mechanisms affecting $\mathrm{Sr} \mathrm{K}_{\mathrm{d}} \mathrm{s}$ are not well understood, a relatively large number of variables were selected initially. The PLS multivariate regression method was chosen for this study because, although the set of variables was large, the PLS regression model can selectively discard unimportant data when generating the regression vector.

Multivariate-regression methods and the collinearity problem are further discussed in Kalivas and Lang (1994). Regression models are useful in relating a specific property to other measurements, but the limits of the data must be known. Construction of a multivariate-regression 
model with variable selection involves finding measurements or combinations of measurements that correlate well with the desired predictive property; therefore, multivariate regression produces a statistically determined model that does not always imply a cause-and-effect relation between the measurements and predictive property.

\section{Collection, Description, and Preparation of Sediment}

Sample collection, preparation, and $\mathrm{K}_{\mathrm{d}}$ determination are described in Liszewski and others (1997). Surficial-sediment samples for this study were collected from 20 selected sites at the INEEL (fig. 3). Most of the sites were near the Radioactive Waste Management Complex, INTEC, TRA, and the Test Area North facilities, where waste is known to have been discharged to the subsurface. Additional samples were collected at sites remote from these facilities to expand the areal extent and range of sediment characteristics included in the study. Sample sites were located near monitoring wells or study areas at the INEEL.

Samples were collected with a hand auger or shovel at a nominal depth of $1 \mathrm{~m}$ to obtain approximately 2 to $4 \mathrm{~kg}$ of sediment. All the samples were homogenized and passed through a $4.7-\mathrm{mm}$ sieve. This material then was crushed to pass through a 2.0-mm sieve and air dried.

Prior to crushing, sediment textures were described on the basis of grain-size distribution of sediment samples (Folk, 1974, p. 28). Textures ranged from sandy gravel to gravelly sand (table 1). Grain-size analysis techniques described by Bartholomay (1990, p. 58) were used to determine the grain-size distribution of sediment samples (table 2). Bulk mineralogy of the samples was determined using $\mathrm{X}$-ray diffraction techniques (Reed and Bartholomay, 1994, p. 5-6) and was variable; quartz, calcite, and plagioclase feldspar generally were the most abundant minerals (table 3). The elemental composition of sediment samples was analyzed using a Jobin Yvon JY 70C Inductively Coupled Plasma (ICP) spectrometer using ICP methodology (table 4). The surface area of each sediment sample was determined using the BET method (Brunauer and others, 1938). BET surface-area was determined using a Micromeritics Gemini 2360 surface area analyzer (table 5). As can be seen from tables 1 through 5 , a wide range of sedimentary properties was represented in the 20 samples.

\section{Methodology and Determination of Partition and Solution Variables}

The sorption studies were carried out using batch experimental techniques. Batch experimental techniques were used because they are relatively simple and inexpensive, and many experiments can be done simultaneously. The dried sediments were homogenized by mechanical mixing and split into nominal 1-g subsamples. The nominal 1-g subsamples were equilibrated with $20.0 \mathrm{~mL}$ of a synthesized aqueous solution at $30^{\circ} \mathrm{C}$ in a constanttemperature shaker (Fisher Scientific Versa-Bath S Model 236) at a setting of 70 cycles per minute for 144 hours. The 1-to-20 mass-to-volume ratio, time of equilibration, and agitation rate were selected to be consistent with those in previous investigations performed by Del Debbio and Thomas (1989), Bunde and others (1997), Hemming and others (1997), Liszewski and others (1997), Bunde and others (1998), Liszewski, Bunde, and others (1998), and Liszewski, Rosentreter and others (1998). The time of equilibration was demonstrated to be sufficient in previous work by Bunde and others (1998). The synthesized aqueous solution chemically represented the wastewater in the INTEC infiltration ponds. The solution contained specific initial concentrations of dissolved carbonate alkalinity, calcium, magnesium, potassium, silica, sodium, and strontium (table 6). The initial $\mathrm{pH}$ of the solution was $8.0 \pm 0.1$. The use of a synthesized aqueous solution allowed for the control of experimental variables, addressed potential saturation problems and chemical-phase modifications, and provided a constant supply of solution (Liszewski, Bunde, and others, 1998).

The aqueous phase was separated from the solid phase at the end of the experiment by centrifugation for 10 minutes at 3,500 revolutions per minute. The supernatant samples were preserved by adding several drops of trace-metal-grade concentrated nitric acid. The initial and sediment-equilibrated solutions were analyzed for alkalinity, cation 




Figure 3. Location of sites where surficial-sediment samples were collected, Idaho National Engineering and Environmental Laboratory. 
concentrations, $\mathrm{pH}$, and specific conductance. Cation concentrations were determined on a Thermo Jarrell Ash Smith-Hieftje 1,000-flame atomic-absorption spectrometer using standard methods for metals in water (Greenberg and others, 1992), pH was measured with an Orion Research model $231 \mathrm{pH}$ meter, specific conductivity was measured using a Fischer Scientific conductivity meter, and alkalinity was determined using a Hach digital titrator. Results of these analyses and measurements were tabulated by Liszewski and others (1997).

Experiments were grouped into sets of 12 replicate subsamples of sediment mixed with synthesized aqueous solution in centrifuge tubes-three replicate sediment subsamples at each of the four strontium concentrations. Additionally, an experimental blank and four control samples were included in each experimental set. The blank consisted of a centrifuge tube containing only deionized water, and control samples consisted of centrifuge tubes containing only synthesized aqueous solution, one at each of the four strontium concentrations. Blanks and controls provided experimental evidence that the constituents in these experiments did not adsorb onto or desorb from the reaction-vessel walls or experimental apparatus. The amount of strontium sorbed to the sediment was calculated from the difference between the initial and equilibrium-solution concentrations multiplied by the volume-to-mass ratio. Sorption isotherms and $K_{d} s$ then were derived using the linear isotherm model (Fetter, 1993).

Sorption isotherms for each surficial-sediment sample were determined from strontium-distribution data at four initial-solution concentrations of strontium (table 6). Strontium linear sorption isotherms and $K_{d} s$ were derived from the leastsquares regression of equilibrium concentrations of strontium sorbed to the sediment as a function of dissolved strontium in solution (Fetter, 1993). Concentrations of dissolved strontium were measured directly by atomic-absorption spectroscopy. Concentrations of sorbed strontium were calculated as the difference between the initial and equilibrium concentrations of dissolved strontium multiplied by the volume-to-mass ratio. Initial concentrations were determined on the basis of the concentration in control samples measured at the conclusion of the experiment. Control samples consisted of reaction vessels containing synthesized aqueous solution with no sediment. It was assumed that any changes that occurred during the experiments in the solution concentrations of the control samples also occurred in the samples. To best represent field conditions in the unsaturated and perched ground-water zones, the sediment was not pretreated with the simulated-wastewater solution before experimentation.

In addition to the solution variables just described, variables describing the sorbed cations also were determined. As detailed previously, the amount of cation lost from solution to the sediment was calculated as the change in ion concentration. The concentration change then was converted to an elemental mass change on the basis of the total volume of solution used in the experiment corrected by the unit mass of sediment found in that particular experiment. Lastly, a corrected sorbed-strontium concentration was defined. In the experiments with no strontium in the synthetic aqueous solution, strontium was found to desorb from the sediment, which produced negative sorption values. Because the $K_{d}$ is derived from the slope of the isotherm, this anomaly did not affect the overall $K_{d}$ value. Yet, the point $K_{d}$ values, those specific $K_{d}$ values calculated for each individual sediment replicate, were affected by this sign change. To avoid this sign change, all sorbedstrontium concentrations were corrected by adding the average mass of desorption for that sediment type to the sorbed-strontium value. As a result, the lowest point $\mathrm{K}_{\mathrm{d}}$ values were adjusted upwards to a value of zero and all other sorbed-strontium concentration were corrected with a similar addition. This process therefore defined and differentiated the sorbed strontium from the sorbed and corrected concentration.

\section{DERIVATION OF THE STRONTIUM DISTRIBUTION COEFFICIENT USING THE LINEAR ISOTHERM MODEL}

The distribution coefficient is defined as (Kipp and others, 1986)

$$
\mathrm{K}_{\mathrm{d}}=[\mathrm{Sr}]_{\mathrm{S}} /[\mathrm{Sr}]_{\mathrm{eq}}
$$


where

$\mathrm{K}_{\mathrm{d}}$ is measured in milliliters per gram;

$[\mathrm{Sr}]_{\mathrm{s}}=$ concentration of sorbed constituent per unit

mass of sediment, in milligrams per kilogram; and

$[\mathrm{Sr}]_{\mathrm{eq}}=$ concentration of dissolved constituent in

the equilibrated solution, in milligrams per liter.

Equilibrium sorption of solutes on sedimentary material commonly is described by the linear isotherm model, in which the $\mathrm{K}_{\mathrm{d}}$ is equal to the slope of a least-squares fit between sorbed- and aqueous-strontium concentrations at equilibrium (Fetter, 1993). Plots of isotherms for the sediments used in the study indicated that the sediments conformed to the linear isotherm mode. Therefore, the slopes of the linear sorption isotherms were used as the $\mathrm{K}_{\mathrm{d}} \mathrm{s}$ in this study.

Experimental values of $[\mathrm{Sr}]_{s}$ were determined through assayed concentrations of aqueous strontium and ratios of solution to sediment:

$$
[\mathrm{Sr}]_{\mathrm{S}}=\left\{[\mathrm{Sr}]_{\mathrm{i}}-[\mathrm{Sr}]_{\mathrm{eq}}\right\} \mathrm{V} / \mathrm{M},
$$

where

$[\mathrm{Sr}]_{\mathrm{i}}=$ initial concentration of aqueous strontium in the solution before equilibration with the sediment, in milligrams per liter,

$\mathrm{V}=$ volume of solution, in milliliters; and

$\mathrm{M}=$ mass of sediment, in grams.

\section{RESULTS AND DISCUSSION}

Strontium $\mathrm{K}_{\mathrm{d}} \mathrm{s}$ of the 20 surficial-sediment samples ranged from $36 \pm 1$ to $275 \pm 3 \mathrm{~mL} / \mathrm{g}$ (table 1). Larger $K_{d}$ values indicate increased strontium sorption by the sediment, which leads to decreased strontium transport.

\section{Variable Selection}

The prediction error of the initially selected variables was evaluated using several criteria. A criteria that can be used for calculating prediction errors is the standard error of calibration (SEC):

$$
\mathrm{SEC}=\frac{\sqrt{\sum_{i=1}^{m}\left(\mathrm{~K}_{\mathrm{d}}-\hat{\mathrm{K}}_{\mathrm{d}}\right)^{2}}}{m},
$$

where $K_{d}$ is the observed and $\hat{K}_{d}$ is the predicted value for the distribution coefficient and $m$ is the number of samples. For information on SEC, see Beebe and others (1998).

Other criteria used for evaluating prediction error were relative error of prediction (REP) and the correlation $(R)$ between observed and predicted $K_{d}$ values for a given variable subset, defined as

$$
\begin{array}{r}
\mathrm{REP}=\frac{\sum_{i=1}^{m}\left|\frac{\left(\mathrm{K}_{\mathrm{d}}-\hat{\mathrm{K}}_{\mathrm{d}}\right)^{2}}{\mathrm{~K}_{\mathrm{d}}}\right|}{m} \text {, and } \\
\mathrm{R}=\frac{\operatorname{cov}\left(\mathrm{K}_{\mathrm{d}}, \hat{\mathrm{K}}_{\mathrm{d}}\right)}{\sqrt{\operatorname{var}\left(\mathrm{K}_{\mathrm{d}}\right) \operatorname{var}\left(\hat{\mathrm{K}}_{\mathrm{d}}\right)}}
\end{array}
$$

where var is the variance and cov is the covariance between the $\mathrm{K}_{d}$ and $\mathrm{K}_{\mathrm{d}}$. See Johnson and Wichern (1988) for additional information on $\mathrm{R}$.

Variable subsets were generated using forward selection (FS). This process was begun by computing prediction error for each variable, one at a time, so that the variable that generated the lowest prediction error was chosen. A two-variable subset subsequently was chosen on the basis of the lowest prediction error. The process continued until the prediction error was not significantly reduced or until all variables were sorted. A limitation of FS is that once a variable is chosen, it becomes part of all subsequent models. However, FS is computationally efficient, because it limits the number of possible models to be analyzed.

\section{Data Pretreatment}

For PLS, data is often pre-treated. Both independent and dependent variables in the data set were mean centered and variance scaled. Computations were performed with MATLAB $4.2 \mathrm{C}$ with the chemometrics TOOLBOX utilities (The MathWorks, Natick, Mass.) on an IBM-compatible, $166-\mathrm{MHz}$, personal computer operating under Windows 95.

Mean-centered variable values are given by

$$
x_{i j}^{*}=x_{i j}-\bar{x}_{j}
$$


Where $x_{i j}$ is the value in row $\mathrm{i}$, column $j$ of $\mathrm{X}$, and $\bar{x}_{j}$ is the mean of column $j$. See Beebe and others (1998) for more information on mean centering. Variance scaling often is used when units for variables in the data set are different; for example, bulk mineralogy (weight percent), chemical concentration (milligrams per liter) and surface area (meters squared per gram). Because PLS attempts to capture variation, variables with numerically larger scales will become more important, even though the information contained in those variables is not inherently greater. Variance scaling is used to place all variables on an equal numerical basis. This is accomplished by normalizing the variables with respect to their variance. The variance scaled variable $x^{* *}{ }_{i j}$ is calculated by

$$
x^{* *}{ }_{i j}=\frac{x^{*}{ }_{i j}}{\operatorname{var}\left(x_{j}\right)}
$$

\section{Experimental Data Set}

Results from the analyses of the 20 surficialsediment samples were used in the variable selection study. Fifty-four variables were determined for each of the sediment samples (table 7). In addition, $\mathrm{Sr} \mathrm{K}_{d}$ values were determined for four different concentrations of $\mathrm{Sr}$ in the aqueous phase used in the batch absorption experiment. Ultimately, the data generated from these experiments consists of 20 different sediments analyzed at four different $\mathrm{Sr}$ concentrations for $80 \mathrm{~K}_{\mathrm{d}}$ experiments, which were performed in triplicate, for a total of $240 \mathrm{~K}_{\mathrm{d}}$ values.

The ability of each variable to predict $\mathrm{Sr} \mathrm{K}_{\mathrm{d}} \mathrm{s}$ for every sediment sample was evaluated using a PLS regression model. All initially selected variables were used during forward selection. Variable subsets of as many as 10 variables were generated using FS as previously described. Variable subsets of 1 to 10 variables were generated using FS. One-, two-, and three-variable subsets generated using FS and one-, two-, and three-variable subsets determined on the basis of all possible combinations were compared. Larger variable-subset determinations based on all possible combinations were impractical because of computational time. Variable subsets (one to three variables) generated by both processes were identical; therefore, it appears that FS identified the best variables.

Table 8 presents the variable subsets generated, together with the number of PLS factors used in generating the predictions that produced the least prediction error from the SEC, REP, and R criteria. A PLS factor represents a vector from the PLS algorithm that contains linear combinations of the variables such that important data variation related to the prediction property is captured (Kalivas, 1999). If too many factors are used, the model begins to overfit the data. When not enough factors are used, the model underfits the data and accurate predictions cannot be made. Inspection of the variable subsets identified using SEC and $\mathrm{R}$ are identical. That is, as the SEC values decrease, $R$ values increase. This agreement is the result of both criteria capturing the same information.

In contrast, different variable subsets were generated when REP was used. The purpose for using REP as an optimization criteria was to identify variable subsets that improved relative error rather than absolute error. Variables identified as best predictors for sediments that had smaller $\mathrm{Sr}$ $\mathrm{K}_{\mathrm{d}} \mathrm{S}$ were expected to be favorably considered, because these subsets would reduce the REP more than sediments that had larger $\mathrm{K}_{\mathrm{d}} \mathrm{s}$.

Table 8 reveals a significant continuous improvement in prediction of $\mathrm{Sr} \mathrm{K}_{\mathrm{d}} \mathrm{s}$ up to the largest (ten variable) subset for SEC. This ten-variable subset regression model produced a correlation of 0.961 and a REP of 11.9 percent. These results suggest that prediction capabilities could be improved by using larger variable subsets, provided PLS is used. That is, by using the ten variables selected by REP and five PLS factors, good results were obtained compared with four-orfive variable models selected by REP. Note that in the smaller variable REP model, two and three PLS factors were needed, which implies that when only a few variables are being used, least squares, rather than PLS, could be satisfactory. Similar observations can be made with respect to SEC and R models.

As discussed in the Theory section, the first variable identified in the FS method is crucial in 
determining the other variables chosen. The first variable selected using REP was sd3. This variable represents a weight fraction of the sediment grainsize distribution. Use of grain-size distribution variables in a regression model has disadvantages. First, reproducibility of this experimental method is relatively low, because of uncertainties involved in the procedure. Second, these variables are likely to be a function of several other variables included in the study, such as mineral composition and surface area. This may produce collinearity in the variable subset and consequently, cause an increase in prediction errors for the regression model. For these reasons, a second variable selection was performed with grain-size distribution variables eliminated from consideration.

Table 9 displays variable selection results generated when grain-size distribution variables are removed from the independent variable list. As expected, the first nine variables chosen with SEC and $R$ were identical. The tenth variable selected by SEC and $\mathrm{R}$ includes $\mathrm{Sr}$, although SEC selects $\mathrm{Sr}_{(\mathrm{c})}$ and $\mathrm{R}$ selects $\mathrm{Sr}_{(\mathrm{s})}$. This difference probably is due to roundoff error by the formulas used in the calculation of the optimization criteria. In any case, it is likely insignificant because the tenth variable has little overall effect on the model. Elimination of grain-size distribution variables generates a difference, with respect to consideration of all variables. For SEC and $\mathrm{R}$ this difference occurs with the selection of the fifth variable. Results in table 9 show a small decrease in predictive performance for variable subsets containing six to eight variables with SEC and R selection. Variable subsets with nine and ten variables show better prediction capabilities when grain-size distribution variables are eliminated.

Examination of the variable selection with the REP criterion in table 9 reveals that 6 out of the 10 variables were the same as those selected with the other criteria. Moreover, the first five variables (S.A., $\mathrm{MnO}^{\mu} \mu \mathrm{S}_{(\mathrm{eq})}, \mathrm{pH}_{(\mathrm{eq})}$, and $\left.\mathrm{Mg}_{(\mathrm{c})}\right)$ chosen by each optimization criterion are the same, except that the variables were chosen in a different order with REP. A comparison of REP variable subsets that includes grain-size distribution variables (table 8) indicates slightly lower prediction errors for subsets with three or fewer variables. When grain-size distribution variables were eliminated, prediction errors with variable subsets of six were slightly lower. Essentially, predictions are approximately the same in tables 8 and 9; however, removal of grain-size distribution variables enhanced agreement among selected variables for the three criteria.

\section{Predictive Equation}

A predictive equation for the $\mathrm{Sr} \mathrm{K}_{\mathrm{d}} \mathrm{S}$ of the surficial-sediment samples used in this study was developed using the PLS regression model. The chemical and physical variables used in the model are given in table 7 . The following equation was obtained from the calibration model within minimized REP using all the sediment samples and no grain-size distribution factor, and is based on a four-variable subset with two PLS factors. After four variables, the REP values did not substantially decrease. The four-variable subset resulted in an average REP of 20 percent and a correlation coefficient of 0.921 between predicted and observed $\mathrm{Sr}$ $\mathrm{K}_{\mathrm{d}} \mathrm{s}$ (table 9):

$$
\begin{aligned}
& \mathrm{K}_{\mathrm{d}}(\mathrm{Sr})=0.3865 \times \text { S.A. }+0.3513 \times \mathrm{MnO} \\
& +0.2696 \times \mu \mathrm{S}_{(\mathrm{eq})}+0.3631 \mathrm{pH}_{(\mathrm{eq})} .
\end{aligned}
$$

$K_{d}$ and $\hat{K}_{d}$ values used in the final predictive equation are plotted in figure 4 . Agreement between observed and predicted values is good. Because the predictive equation was obtained using mean-centered and variance-scaled variables, data used in the equation must be treated in the same manner. Once the predictive $\mathrm{K}_{\mathrm{d}} \mathrm{s}$ are obtained, unscaling of the $K_{d}$ pretreatment is required prior to comparison with observed $\mathrm{K}_{\mathrm{d}} \mathrm{s}$.

\section{CONCLUSIONS}

The simple predictive equation (11) suggests that $\mathrm{Sr} \mathrm{K}_{\mathrm{d}} \mathrm{s}$ can be adequately predicted using only a few easily measured solution and sediment characteristics. This is true only when the range of sample and solution types is carefully defined; however, because this range is often a function of the local environment, use of the equation would be a suitable approach for studies of localized geographic regions. 




Figure 4. Predicted strontium distribution coefficients $\left(\mathrm{Sr} \mathrm{K}_{d} \mathrm{~s}\right)$ with respect to observed $\mathrm{Sr}$ $\mathrm{K}_{\mathrm{d}} \mathrm{s}$ for the data set without grain-size distributions using two partial least-square factors with the four variables $\mathrm{MnO}, \mu \mathrm{S}, \mathrm{pH}$, and $\mathrm{SA}$. 
In the numerical investigations, the most appropriate modeling technique differed, depending on how many variables were used in the prediction equation. Data in this report indicates that when only a few variables were selected, a simple leastsquares approach was satisfactory. When a large number of variables was used in the prediction equation, PLS provided a superior model. In this study, a PLS approach with four variables provided an accurate prediction equation. Although the variables selected in this study represent the result of an empirical model, they also can aid in the identification of variables important to the development of future mechanistic models.

\section{REFERENCES CITED}

Anderson, S.R., 1991, Stratigraphy of the unsaturated zone and uppermost part of the Snake River Plain aquifer at the Idaho Chemical Processing Plant and Test Reactors Area, Idaho National Engineering Laboratory, Idaho: U.S. Geological Survey WaterResources Investigations Report 91-4010, 71 p.

Bartholomay, R.C., 1990, Mineralogy, petrology and grain size of surficial sediment from the Big Lost River, Little Lost River, and Birch Creek drainages, Idaho National Engineering Laboratory, Idaho: Pocatello, Idaho State University, M.S. thesis, $118 \mathrm{p}$.

-----, 1998, Distribution of selected radiochemical and chemical constituents in perched ground water, Idaho National Engineering Laboratory, Idaho, 1992-95: U.S. Geological Survey Water-

Resources Investigations Report 98-4026, 59 p.

Bartholomay, R.C., Orr, B.R., Liszewski, M.J., and Jensen, R.G., 1995, Hydrologic conditions and distribution of selected chemical constituents in water, Snake River Plain aquifer, Idaho National Engineering Laboratory, Idaho, 1989 through 1991: U.S. Geological Survey Water-Resources Investigations Report 95-4175, 47 p.

Bartholomay, R.C., Tucker, B.J., Ackerman, D.J., and Liszewski, M.J., 1997, Hydrologic conditions and distribution of selected radiochemical and chemical constituents in water, Snake River Plain aquifer, Idaho National Engineering Laboratory, Idaho, 1992 through 1995: U.S. Geological Survey Water-Resources Investigations Report 97-4086, $57 \mathrm{p}$.
Beebe, K.R., Pell, R.J., and Seasholtz, M.B., 1998, Chemometrics, a practical guide: New York, John Wiley and Sons, Inc., p. 183-338.

Bohn, H.L., 1985, Soil chemistry: New York, John Wiley and Sons, Inc., 341 p.

Brunauer, S., Emmett, P.H., and Teller, E., 1938, Adsorption of gases in multimolecular layers: Journal of American Chemical Society, v. 60, p. 309-319.

Bunde, R.L., Rosentreter, J.J., and Liszewski, M.J., 1998, Rate of strontium sorption and the effects of variable aqueous concentrations of sodium and potassium on strontium distribution coefficients of a surficial sediment at the Idaho National Engineering Laboratory, Idaho: Environmental Geology, v. 34, no. 2-3, p. 135-142.

Bunde, R.L., Rosentreter, J.J., Liszewski, M.J., Hemming, C.H., and Welhan, J., 1997, Effects of calcium and magnesium on strontium distribution coefficients: Environmental Geology, v. 32, no. 3, p. 219-229.

Del Debbio, J.A., and Thomas, T.R., 1989, Transport properties of radionuclides and hazardous chemical species in soils at the Idaho Chemical Processing Plant, Idaho Falls, Idaho: Westinghouse Idaho Nuclear Company, Inc., WINCO-1068, variously paged.

Eisenbud, M., 1973, Environmental radioactivity: New York and London, Academic Press, 542 p.

Fetter, C.W., 1993, Contaminant hydrogeology: New York, MacMillan International, 458 p.

Folk, R.L., 1974, Petrology of sedimentary rocks: Austin, Tex., Hemphill Publishing Company, 182 p.

Greenberg, A.E., Clesceri, L.S., and Eaton, A.D., eds., 1992, Standard methods for the examination of water and wastewater, 18th ed.: American Public Health Association, American Water Works Association, Water Environment Federation, variously paged.

Hawkins, D.B., and Short, H.L., 1965, Equations for the sorption of cesium and strontium on soil and clinoptilolite: U.S. Atomic Energy Commission, Idaho Operations Office, IDO-12046, 33 p. 
Hemming, C.H., Bunde, R.L., Liszewski, M.J., Rosentreter, J.J., and Welhan, J., 1997, Effect of experimental technique on the determination of strontium distribution coefficients of a surficial sediment from the Idaho National Engineering Laboratory, Idaho: Water Research, v. 31, no. 7, p. 1629-1636.

Inch, K.J., and Killey, R.W.D., 1987, Surface area and radionuclide sorption in contaminated aquifers: Water Pollution Research Journal of Canada, $v$. 22, p. 85-98.

Jackson, R.E., and Inch, K.J., 1983, Partitioning of strontium-90 among aqueous and mineral species in a contaminated aquifer: Environmental Science and Technology, v. 17, p. 231-237.

Johnson, R.A., and Wichern, D.W., 1988, Applied multivariate statistical analysis: Englewood Cliffs, N.J., Prentice Hall, p. 273-338.

Kalivas, J.H., 1999, Interrelationships of multivariate regression methods using Eisenvector basis sets: Journal of Chemometrics, v. 13, p. 111-132.

Kalivas, J.H., and Lang, P., 1994, Mathematical analysis of spectral orthogonality: New York, Marcel Dekker, 230 p.

Kenna, B.T., 1980, Temperature and $\mathrm{pH}$ effects on sorption properties of subseabed clay: Annual Meeting of the Materials Research Society, 8 p.

Kipp, K.L., Stollenwerk, K.G., and Grove, D.B., 1986, Groundwater transport of strontium-90 in a glacial outwash environment: Water Resources Research, v. 22 , p. $519-530$.

Liszewski, M.J., Bunde, R.L., Hemming, C.H., Rosentreter, J.J., and Welhan, J., 1998, The use of synthesized aqueous solutions for determining strontium sorption isotherms: Journal of Contaminant Hydrology, v. 29, p. 93-108.

Liszewski, M.J., Rosentreter, J.J., and Miller, K.E., 1997, Strontium distribution coefficients of surficial sediment samples from the Idaho National Engineering Laboratory, Idaho: U.S. Geological Survey Water-Resources Investigations Report 974044, 33 p.

Liszewski, M.J., Rosentreter, J.J., Miller, K.E., and Bartholomay, R.C., 1998, Strontium distribution coefficients of surficial and sedimentary interbed samples from the Idaho National Engineering and
Environmental Laboratory, Idaho: U.S. Geological Survey Water-Resources Investigations Report 984073, $55 \mathrm{p}$.

Mundorff, M.J., Crosthwaite, E.G., and Kilburn, C., 1964 , Ground water for irrigation in the Snake River Basin in Idaho: U.S. Geological Survey Water-Supply Paper 1654, 224 p.

Newman, M.E., Porro, I., Scott, R., Dunnivant, F.M., Goff, R.W., Blevins, M.P., Ince, S.M., Leyba, J.D., Devol, T.A., Elzerman, A.W., and Fjeld, R.A., 1996, Evaluation of the mobility of Am, Cs, Co, $\mathrm{Pu}, \mathrm{Sr}$, and $\mathrm{U}$ through INEL basalt and interbed materials: Summary report of the INEL/Clemson University Laboratory Studies, WAG7-82, INEL95/282, September 19, [variously paged].

Park, C.K., Woo, S.I., Tanaka, T., and Kamiyama, H., 1992 , Sorption and desorption behavior of ${ }^{60} \mathrm{Co}$, ${ }^{85} \mathrm{Sr}$, and ${ }^{137} \mathrm{Cs}$ in a porous tuff, mechanisms and kinetics: Journal of Nuclear Science Technology, v. 29, p. 1184-1193.

Patterson, R.J., and Spoel, T., 1981, Laboratory measurements of strontium distribution coefficient, $K_{d}$, for sediments from a shallow sand aquifer: Water Resources Research, v. 17, p. 513520 .

Pittman, J.R., Jensen, R.G., and Fischer, P.R., 1988, Hydrologic conditions at the Idaho National Engineering Laboratory, 1982 to 1985: U.S. Geological Survey Water-Resources Investigations Report 89-4008, 73 p.

Qingzhong, B., and Guangyu, Y., 1989, Experimental study on $\mathrm{Cs}$ and $\mathrm{Sr}$ transport in soil medium: Journal of Tsinghua University, Science and Technology, v. 29, p. 96-104.

Rafferty, P., Shiao, S.Y., Binz, C.M., and Meyer, R.E ., 1981, Adsorption of $\mathrm{Sr}$ (II) on clay minerals: Effects of salt concentration, loading and $\mathrm{pH}$ : Journal of Inorganic Nuclear Chemistry, v. 43, no. 4, p. 797-805.

Reed, M.F., and Bartholomay, R.C., 1994, Mineralogy of selected sedimentary interbeds at or near the Idaho National Engineering Laboratory, Idaho: U.S. Geological Survey Open-File Report 94-374, $19 \mathrm{p}$. 
Robertson, A.P., and Leckie, J.O., 1991, Cation binding predictions of surface complexation models: Journal of Colloid and Interface Science, v. 188, $444 \mathrm{p}$.

Robertson, J.B., Schoen, R., and Barraclough, J.T., 1974 , The influence of liquid waste disposal on the geochemistry of water at the National Reactor Testing Station, Idaho, 1952-70: U.S. Geological Survey Open-File Report, IDO-22053, 231 p.

Rosentreter, J.J., Quarder, H.S., Smith, R.W., and McLing, T., 1997, Uranium sorption onto natural sands as a function of sediment characteristics and solution $\mathrm{pH}$, in Metal Adsorption by Earth Materials: San Diego, Calif., Academic Press, p. 181-192.

Schmalz, B.L., 1972, Radionuclide distribution in soil mantle of the lithosphere as a consequence of waste disposal at the National Reactor Testing Station: U.S. Atomic Energy Commission, Idaho Operations Office, IDO-10049, $80 \mathrm{p}$.

Schnoor, J.L., 1996, Environmental modeling fate and transport of pollutants in water, air and soil: New York, John Wiley and Sons, Inc., $682 \mathrm{p}$.

Sibley, T.H., Sanchez, A.L., Wurtz, E.A., and Schnell, W.R., 1982, Distribution coefficients for radionuclides in aquatic environments: Effect of $\mathrm{pH}$ on adsorption: Washington, D.C., Nuclear Regulatory Commission, Office of Nuclear Regulatory Research, 63 p.

Sposito, G., 1989, The chemistry of soils: New York, Oxford University Press, $277 \mathrm{p}$.

Tadao, T., and Tadatoshi, Y., 1988, Effect of soil characteristics on soil particle size dependence of distribution coefficient: Journal of the Atomic Energy Society of Japan, v. 30, p. 933-941.

U.S. Environmental Protection Agency, 1997, Protection of environment, Code of Federal Regulations 40: Office of the Federal Register, National Archives and Records Administration, Parts 136 to $149,766 \mathrm{p}$. 
Table 1. Sample depth, texture, and distribution coefficients of surficial-sediment samples from the Idaho National Engineering and Environmental Laboratory

[Depth is the approximate depth below land surface at which the sample was collected. Abbreviations: $m$, meter; $K_{d}$, distribution coefficient; $\mathrm{mL} / \mathrm{g}$, milliliters per gram. Texture descriptions are from Folk $(1974, \mathrm{p} .28) . \mathrm{K}_{\mathrm{d}}$ uncertainties are the standard error of the linear regression used to calculate the $\mathrm{K}_{\mathrm{d}}$ ]

\begin{tabular}{cccc}
\hline Sample name & Depth $(\mathrm{m})$ & Texture & $\mathrm{K}_{\mathrm{d}}(\mathrm{mL} / \mathrm{g})$ \\
\hline BC-1 & 0.7 & Sandy gravel & $68 \pm 5$ \\
BC-2 & .8 & Sandy gravel & $94 \pm 2$ \\
BC-3 & 1 & Sandy gravel & $66 \pm 4$ \\
BC-4 & 1 & Gravelly sand & $97 \pm 3$ \\
BC-5 & 1 & Gravelly sand & $61 \pm 3$ \\
BC-6 & 1 & Gravelly sand & $134 \pm 3$ \\
BC-7 & 1 & Gravelly sand & $204 \pm 4$ \\
BC-8 & 1 & Slightly gravelly, muddy sand & $266 \pm 3$ \\
BC-9 & 1 & Gravelly sand & $275 \pm 3$ \\
BC-10 & 1 & Sandy gravel & $167 \pm 2$ \\
BC-11 & .7 & Sandy gravel & $36 \pm 1$ \\
BC-12 & 1 & Gravelly sand & $89 \pm 2$ \\
BC-13 & 1 & Gravelly, muddy sand & $208 \pm 2$ \\
BC-14 & 1 & Gravelly sand & $118 \pm 3$ \\
BC-15 & 1 & Gravelly sand & $157 \pm 1$ \\
BC-16 & 1 & Gravelly sand & $203 \pm 3$ \\
BC-17 & 1 & Gravelly sand & $96 \pm 4$ \\
BC-18 & 1 & Gravelly, muddy sand & $209 \pm 3$ \\
BC-19 & 1 & Gravelly, muddy sand & $88 \pm 4$ \\
BC-20 & 1 & Sandy gravel & $67 \pm 2$ \\
\hline & 1 & & \\
\hline & 1 & 1 & 1 \\
\hline
\end{tabular}


Table 2. Grain-size distribution of surficial-sediment samples from the Idaho National Engineering and Environmental Laboratory

[All size intervals are in millimeters. Grain-size distribution determined using grain-size analysis techniques described by Bartholomay (1990). Abbreviations: >, greater than; <, less than]

\begin{tabular}{|c|c|c|c|c|c|c|c|c|c|}
\hline \multirow{2}{*}{$\begin{array}{l}\text { Sample } \\
\text { name }\end{array}$} & \multicolumn{9}{|c|}{ Grain-size distribution, in weight percent } \\
\hline & $>4.75$ & $4.75-4.0$ & $4.0-2.0$ & $2.0-1.0$ & $1.0-0.5$ & $0.5-0.25$ & $0.25-0.125$ & $0.125-0.063$ & $<0.063$ \\
\hline $\mathrm{BC}-1$ & 46.1 & 4.5 & 11.0 & 6.4 & 5.9 & 10.6 & 6.7 & 6.1 & 2.7 \\
\hline BC-2 & 30.7 & 2.9 & 7.6 & 4.9 & 4.5 & 13.7 & 18.1 & 10.8 & 6.9 \\
\hline $\mathrm{BC}-3$ & 41.8 & 3.5 & 8.4 & 5.1 & 6.7 & 18.8 & 6.8 & 6.0 & 2.8 \\
\hline BC-4 & 0 & 2.0 & 13.2 & 11.3 & 14.4 & 30.2 & 18.2 & 8.8 & 2.0 \\
\hline BC-5 & 45.3 & 3.1 & 7.5 & 4.0 & 5.1 & 22.0 & 9.6 & 2.7 & .7 \\
\hline BC- 6 & 36.0 & 2.5 & 5.6 & 5.3 & 11.2 & 25.6 & 8.0 & 4.5 & 1.3 \\
\hline BC-7 & 0 & 8.4 & 29.9 & 22.8 & 20.6 & 16.7 & 1.3 & .2 & 0 \\
\hline$B C-8$ & 1.4 & .3 & 1.9 & 7.3 & 11.2 & 10.5 & 13.3 & 38.3 & 16.0 \\
\hline BC-9 & 0 & 4.5 & 18.3 & 19.0 & 19.6 & 15.0 & 11.5 & 10.0 & 2.1 \\
\hline BC- 10 & 0 & 6.5 & 30.9 & 24.0 & 25.5 & 10.9 & 1.6 & .6 & .1 \\
\hline BC-11 & 55.4 & 3.6 & 9.6 & 5.9 & 4.5 & 11.2 & 5.4 & 2.8 & 1.7 \\
\hline BC-12 & 0 & .7 & 14.5 & 14.4 & 11.9 & 14.2 & 25.8 & 13.2 & 5.3 \\
\hline BC-13 & .7 & .7 & 10.5 & 11.0 & 10.5 & 9.0 & 16.7 & 26.0 & 14.9 \\
\hline BC-14 & 0 & 1.2 & 11.1 & 9.7 & 8.0 & 11.3 & 37.3 & 18.0 & 3.4 \\
\hline BC- 15 & 0 & .8 & 15.2 & 21.6 & 18.8 & 13.2 & 12.7 & 16.5 & 1.0 \\
\hline BC-16 & 0 & 2.7 & 18.1 & 22.2 & 19.0 & 13.2 & 11.4 & 10.0 & 3.3 \\
\hline BC-17 & 0 & 2.7 & 19.2 & 25.9 & 20.8 & 12.3 & 7.1 & 8.9 & 3.1 \\
\hline BC-18 & 1.6 & 1.4 & 12.3 & 13.3 & 12.8 & 10.8 & 11.9 & 18.0 & 18.0 \\
\hline BC-19 & 6.2 & 1.4 & 12.6 & 15.2 & 13.5 & 9.7 & 14.1 & 17.8 & 9.5 \\
\hline BC-20 & 48.5 & 3.7 & 10.8 & 8.6 & 8.9 & 12.6 & 4.5 & 1.3 & 1.0 \\
\hline
\end{tabular}


Table 3. Bulk mineralogy of surficial-sediment samples from the Idaho National Engineering and Environmental Laboratory

[Bulk mineralogy determined using X-ray diffraction techniques (Reed and Bartholomay, 1994, p. 5-6). Abbreviations: Qz, quartz; $\mathrm{Pg}$, plagioclase feldspar; Ksp, potassium feldspar, Cc, calcite; T.C., total clay minerals; Dol, dolomite; Py, pyroxene]

\begin{tabular}{|c|c|c|c|c|c|c|c|}
\hline \multirow{2}{*}{ Sample name } & \multicolumn{7}{|c|}{ Bulk mineralogy, in weight percent } \\
\hline & Qz & $\mathbf{P g}$ & Ksp & Cc & T.C. & Dol & Py \\
\hline BC-1 & 48 & 13 & 9 & 11 & 7 & 0 & 9 \\
\hline $\mathrm{BC}-2$ & 51 & 24 & 5 & 7 & 10 & 0 & 2 \\
\hline $\mathrm{BC}-3$ & 63 & 22 & 0 & 16 & 0 & 0 & 0 \\
\hline BC-4 & 56 & 19 & 0 & 3 & 22 & 0 & 0 \\
\hline BC-5 & 41 & 21 & 12 & 12 & 0 & 0 & 14 \\
\hline BC-6 & 41 & 18 & 13 & 8 & 21 & 0 & 0 \\
\hline BC-7 & 42 & 24 & 0 & 5 & 21 & 0 & 8 \\
\hline BC-8 & 39 & 15 & 0 & 15 & 10 & 7 & 15 \\
\hline BC-9 & 45 & 18 & 0 & 11 & 26 & 0 & 0 \\
\hline BC-10 & 52 & 16 & 0 & 25 & 0 & 6 & 0 \\
\hline BC-11 & 26 & 0 & 0 & 69 & 0 & 5 & 0 \\
\hline BC-12 & 29 & 17 & 0 & 27 & 15 & 12 & 0 \\
\hline BC-13 & 25 & 14 & 0 & 51 & 0 & 10 & 0 \\
\hline BC-14 & 30 & 6 & 0 & 52 & 0 & 12 & 0 \\
\hline BC-15 & 27 & 0 & 0 & 41 & 24 & 9 & 0 \\
\hline BC-16 & 21 & 4 & 10 & 42 & 17 & 6 & 0 \\
\hline BC-17 & 28 & 12 & 0 & 35 & 19 & 7 & 0 \\
\hline BC-18 & 41 & 13 & 0 & 28 & 10 & 8 & 0 \\
\hline BC-19 & 33 & 7 & 0 & 40 & 13 & 7 & 0 \\
\hline BC-20 & 47 & 30 & 0 & 4 & 4 & 7 & 9 \\
\hline
\end{tabular}


Table 4. Whole-rock analysis of selected major, minor, and trace elements in surficial-sediment samples from the Idaho National Engineering and Environmental Laboratory

[Silicon, titanium, aluminum, iron, manganese, magnesium, calcium, sodium, and potassium are reported as oxide concentrations. Strontium and barium are reported as elemental concentrations. Whole-rock analysis determined using inductively coupled plasma techniques. Abbreviations: ppm, parts per million; $\mathrm{SiO}_{2}$, silicon dioxide; $\mathrm{TiO}_{2}$, titanium dioxide; $\mathrm{Al}_{2} \mathrm{O}_{3}$, aluminum oxide; $\mathrm{Fe}_{2} \mathrm{O}_{3}$. iron oxide; $\mathrm{MnO}$, manganese oxide; $\mathrm{MgO}$, magnesium oxide; $\mathrm{CaO}$, calcium oxide; $\mathrm{Na}_{2} \mathrm{O}$, sodium oxide; $\mathrm{K}_{2} \mathrm{O}$, potassium oxide; $\mathrm{Sr}$, strontium; $\mathrm{Ba}$, barium]

\begin{tabular}{|c|c|c|c|c|c|c|c|c|c|c|c|}
\hline \multirow{2}{*}{$\begin{array}{l}\text { Sample } \\
\text { name }\end{array}$} & \multicolumn{9}{|c|}{ Whole-rock analysis, in weight percent } & \multicolumn{2}{|c|}{ ppm } \\
\hline & $\mathrm{SiO}_{2}$ & $\mathrm{TiO}_{2}$ & $\mathbf{A l}_{2} \mathrm{O}_{3}$ & $\mathrm{Fe}_{2} \mathrm{O}_{3}$ & Mno & MgO & $\mathrm{CaO}$ & $\mathrm{Na}_{2} \mathrm{O}$ & $\mathbf{K}_{2} \mathbf{O}$ & $\mathrm{Sr}$ & $\mathrm{Ba}$ \\
\hline BC-1 & 73.60 & 0.47 & 9.93 & 3.15 & 0.045 & 1.25 & 4.79 & 1.61 & 2.76 & 262 & 6,180 \\
\hline BC-2 & 72.90 & .47 & 10.90 & 3.22 & .049 & 1.73 & 3.64 & 1.72 & 2.74 & 262 & 6,620 \\
\hline$B C-3$ & 71.70 & .48 & 10.15 & 3.27 & .045 & 1.32 & 4.82 & 1.67 & 2.72 & 270 & 6,160 \\
\hline$B C-4$ & 70.60 & .56 & 12.10 & 4.03 & .057 & 2.30 & 4.25 & 1.57 & 2.60 & 234 & 6,280 \\
\hline BC-5 & 70.70 & .54 & 10.03 & 4.00 & .050 & 1.54 & 4.94 & 1.65 & 2.70 & 291 & 6,285 \\
\hline BC- 6 & 72.50 & .53 & 10.90 & 3.81 & .054 & 1.77 & 4.22 & 1.66 & 2.75 & 213 & 6,320 \\
\hline $\mathrm{BC}-7$ & 70.20 & .69 & 13.80 & 4.69 & .049 & 1.71 & 2.87 & 1.30 & 2.65 & 167 & 4,610 \\
\hline BC-8 & 66.20 & .60 & 11.20 & 3.87 & .076 & 2.50 & 5.43 & 1.45 & 2.37 & 207 & 4,660 \\
\hline BC-9 & 67.27 & .67 & 11.97 & 4.24 & .085 & 1.95 & 4.67 & 1.43 & 2.18 & 232 & 4,547 \\
\hline BC-10 & 63.50 & .59 & 11.20 & 4.04 & .078 & 2.22 & 6.94 & 1.22 & 2.30 & 162 & 4,540 \\
\hline BC-11 & 47.10 & .18 & 3.43 & 1.15 & .019 & 1.49 & 22.70 & .28 & 1.10 & 167 & 1,031 \\
\hline BC-12 & 63.40 & .46 & 10.80 & 3.52 & .062 & 2.41 & 8.00 & 1.59 & 2.47 & 262 & 6,510 \\
\hline BC-13 & 50.70 & .45 & 7.45 & 3.03 & .056 & 3.32 & 17.10 & .93 & 1.61 & 230 & 3,210 \\
\hline BC-14 & 61.80 & .40 & 9.29 & 2.95 & .047 & 2.47 & 10.40 & 1.18 & 2.18 & 278 & 4,590 \\
\hline BC-15 & 54.20 & .50 & 10.80 & 4.15 & .073 & 2.94 & 12.00 & .92 & 2.36 & 234 & 4,960 \\
\hline BC-16 & 44.80 & .38 & 9.31 & 3.33 & .056 & 2.92 & 18.00 & .60 & 2.01 & 182 & 3,950 \\
\hline BC-17 & 51.10 & .46 & 10.80 & 3.70 & .068 & 2.61 & 13.20 & .87 & 2.20 & 156 & 3,860 \\
\hline BC-18 & 58.70 & .59 & 9.68 & 3.80 & .083 & 2.78 & 10.50 & 1.32 & 1.91 & 151 & 3,670 \\
\hline BC-19 & 50.80 & .50 & 8.75 & 3.24 & .057 & 3.32 & 13.00 & 1.54 & 1.79 & 234 & 3,820 \\
\hline BC-20 & 75.20 & .49 & 10.80 & 3.29 & .044 & 1.41 & 2.50 & 1.86 & 2.82 & 231 & 6,930 \\
\hline
\end{tabular}


Table 5. Brunauer-Emmett-Teller surface area of surficial-sediment samples from the Idaho National Engineering and Environmental Laboratory

TThe surface area of each sediment sample was determined using the Brunauer-Emmett-Teller (BET) method (Brunauer and others, 1938). BET surface area was determined using a Micromeritics Gemini 2360 surface-area analyzer. Abbreviations: $\mathrm{m}^{2} / \mathrm{g}$, meters squared per gram]

\begin{tabular}{lc}
\hline Sample name & Surface area $\left(\mathrm{m}^{2} / \mathrm{g}\right)$ \\
\hline BC-1 & 6.6 \\
BC-2 & 8.7 \\
BC-3 & 6.9 \\
BC-4 & 16.8 \\
BC-5 & 7.0 \\
BC-6 & 10.6 \\
BC-7 & 58.4 \\
BC-8 & 31.2 \\
BC-9 & 37.2 \\
BC-10 & 35.1 \\
BC-11 & 4.4 \\
BC-12 & 13.8 \\
BC-13 & 21.7 \\
BC-14 & 15.3 \\
BC-15 & 25.9 \\
BC-16 & 24.0 \\
BC-17 & 23.6 \\
BC-18 & 22.8 \\
BC-19 & 33.9 \\
BC-20 & 4.1 \\
\hline & \\
\hline & \\
\hline
\end{tabular}


Table 6. Concentrations of alkalinity, calcium, magnesium, potassium, silica, sodium, strontium, and pH in the two batches of synthesized aqueous solutions used in the strontium batch experiments

[Alkalinity was determined using a Hach digital titrator. Calcium, magnesium, potassium, sodium, and strontium concentrations determined by assay using atomic-absorption spectroscopy. Silica concentrations determined by calculation on the basis of the amount added. $\mathrm{pH}$ was measured using an Orion Research model $231 \mathrm{pH}$ meter. Sodium concentrations include sodium additions from sodium bicarbonate, sodium hydroxide, and sodium silicate. Abbreviations: $\mathrm{mg} / \mathrm{L}$, milligrams per liter; $\mathrm{CaCO}_{3}$, calcium carbonate; $\mathrm{SiO}_{2}$, silicon dioxide; <, less than]

\begin{tabular}{ccccccccc}
\hline $\begin{array}{c}\text { Batch } \\
\text { number }\end{array}$ & $\begin{array}{c}\text { Alkalinity } \\
(\mathbf{m g / L} \text { as } \\
\left.\mathrm{CaCO}_{3}\right)\end{array}$ & $\begin{array}{c}\text { Calcium } \\
(\mathrm{mg} / \mathrm{L})\end{array}$ & $\begin{array}{c}\text { Magnesium } \\
(\mathrm{mg} / \mathbf{L})\end{array}$ & $\begin{array}{c}\text { Potassium } \\
(\mathrm{mg} / \mathbf{L})\end{array}$ & $\begin{array}{c}\text { Silica(mg/L } \\
\left.\text { as } \mathrm{SiO}_{2}\right)\end{array}$ & $\begin{array}{c}\text { Sodium } \\
(\mathrm{mg} / \mathbf{L})\end{array}$ & $\begin{array}{c}\text { Strontium } \\
(\mathbf{m g} / \mathbf{L})\end{array}$ & $\mathbf{p H}$ \\
\hline 1 & 95 & 11 & 1.9 & 1.9 & 21 & 110 & $<0.02$ & 7.95 \\
& 96 & 11 & 1.9 & 1.9 & 21 & 104 & 1.1 & 7.94 \\
& 96 & 11 & 1.9 & 1.9 & 21 & 122 & 2.5 & 7.94 \\
& 95 & 11 & 1.9 & 1.9 & 21 & 115 & 5.4 & 7.92 \\
& 99 & 11 & 1.9 & 1.9 & 21 & 84 & $<.02$ & 8.04 \\
& 98 & 11 & 1.9 & 1.9 & 21 & 86 & 1.1 & 8.10 \\
& 95 & 11 & 1.9 & 1.9 & 21 & 92 & 2.7 & 8.08 \\
& 100 & 12 & 1.9 & 1.9 & 21 & 100 & 5.4 & 8.06 \\
\hline
\end{tabular}


Table 7. Chemical and physical variables describing the aqueous solution and sediments measured in each experimental distribution coefficient determination

[Units of measurement: $\mathrm{mg} / \mathrm{L}$, milligrams per liter; $\mu \mathrm{S} / \mathrm{cm}$, microsiemens per centimeter; wt $\%$, weight percent; $\mathrm{mg} / \mathrm{kg}$, milligrams per kilogram; $\mathrm{m}^{2} / \mathrm{g}$, meters squared per gram; >, greater than; $\mathrm{mm}$, millimeter, <, less than]

\begin{tabular}{|c|c|c|c|}
\hline Variable & Symbol & Type of variable & $\begin{array}{c}\text { Units of } \\
\text { measurement }\end{array}$ \\
\hline Strontium (equilibrium) & $\operatorname{Sr}(e q)$ & Solution & mg/L \\
\hline Strontium (change) & $\operatorname{Sr}(c)$ & solution & $\mathrm{mg} / \mathrm{L}$ \\
\hline Strontium (sorbed) & $\operatorname{Sr}(s)$ & solution & $\mathrm{mg} / \mathrm{L}$ \\
\hline Strontium (sorbed, corrected) & $\operatorname{Sr}(s, c)$ & solution & $\mathrm{mg} / \mathrm{L}$ \\
\hline Calcium (initial) & $\mathrm{Ca}(\mathrm{i})$ & solution & $\mathrm{mg} / \mathrm{L}$ \\
\hline Calcium (equilibrium) & $\mathrm{Ca}(\mathrm{eq})$ & solution & $\mathrm{mg} / \mathrm{L}$ \\
\hline Calcium (change) & $\mathrm{Ca}(\mathrm{c})$ & solution & $\mathrm{mg} / \mathrm{L}$ \\
\hline Calcium (sorbed) & $\mathrm{Ca}(\mathrm{s})$ & solution & $\mathrm{mg} / \mathrm{L}$ \\
\hline Magnesium (initial) & $\mathrm{Mg}(\mathrm{i})$ & solution & $\mathrm{mg} / \mathrm{L}$ \\
\hline Magnesium (equilibrium) & $\mathrm{Mg}(\mathrm{eq})$ & solution & $\mathrm{mg} / \mathrm{L}$ \\
\hline Magnesium (change) & $\mathrm{Mg}(\mathrm{c})$ & solution & $\mathrm{mg} / \mathrm{L}$ \\
\hline Magnesium (sorbed) & $\operatorname{Mg}(s)$ & solution & $\mathrm{mg} / \mathrm{L}$ \\
\hline Potassium (initial) & $\mathrm{K}(\mathrm{i})$ & solution & $\mathrm{mg} / \mathrm{L}$ \\
\hline Potassium (equilibrium) & $K(e q)$ & solution & $\mathrm{mg} / \mathrm{L}$ \\
\hline Potassium (change) & $K(c)$ & solution & $\mathrm{mg} / \mathrm{L}$ \\
\hline Potassium (sorbed) & $\mathrm{K}(\mathrm{s})$ & solution & $\mathrm{mg} / \mathrm{L}$ \\
\hline Sodium (initial) & $\mathrm{Na}(\mathrm{i})$ & solution & $\mathrm{mg} / \mathrm{L}$ \\
\hline Sodium (equilibrium) & $\mathrm{Na}(\mathrm{eq})$ & solution & $\mathrm{mg} / \mathrm{L}$ \\
\hline Sodium (change) & $\mathrm{Na}(\mathrm{c})$ & solution & $\mathrm{mg} / \mathrm{L}$ \\
\hline Sodium (sorbed) & $\mathrm{Na}(\mathrm{s})$ & solution & $\mathrm{mg} / \mathrm{L}$ \\
\hline $\mathrm{pH}$ (initial) & $\mathrm{pH}(\mathrm{i})$ & solution & $\mathrm{pH}$ \\
\hline pH (equilibrium) & $\mathrm{pH}(\mathrm{eq})$ & solution & $\mathrm{pH}$ \\
\hline pH (change) & $\mathrm{pH}(\mathrm{c})$ & solution & $\mathrm{pH}$ \\
\hline Specific conductance (initial) & $\mu S(i)$ & solution & $\mu \mathrm{S} / \mathrm{cm}$ \\
\hline Specific conductance (equilibrium) & $\mu S($ eq) & solution & $\mu \mathrm{S} / \mathrm{cm}$ \\
\hline Specific conductance (change) & $\mu S(c)$ & solution & $\mu \mathrm{S} / \mathrm{cm}$ \\
\hline Quartz & $\mathrm{Qz}$ & solid & wt $\%$ \\
\hline Plagioclase feldspar & $\mathrm{Pg}$ & solid & wt $\%$ \\
\hline Potassium feldspar & $\mathrm{Ksp}$ & solid & wt $\%$ \\
\hline Calcite & $\mathrm{Cc}$ & solid & wt $\%$ \\
\hline Total clay minerals & T.C. & solid & wt $\%$ \\
\hline Dolomite & Dol & solid & wt $\%$ \\
\hline Pyroxene & Py & solid & wt \% \\
\hline Grain size $>4.75 \mathrm{~mm}$ & sdil 1 & solid & wt $\%$ \\
\hline Grain size $4.0-4.75 \mathrm{~mm}$ & $\mathrm{sd} 2$ & solid & wt $\%$ \\
\hline Grain size $2.0-4.0 \mathrm{~mm}$ & sd3 & solid & wt $\%$ \\
\hline Grain size $1.0-2.0 \mathrm{~mm}$ & sd4 & solid & wt \% \\
\hline Grain size $0.5-1.0 \mathrm{~mm}$ & sd5 & solid & wt \% \\
\hline Grain size $0.25-0.5 \mathrm{~mm}$ & sd6 & solid & wt \% \\
\hline Grain size $0.125-0.25 \mathrm{~mm}$ & sd7 & solid & wt \% \\
\hline Grain size $0.063-0.125 \mathrm{~mm}$ & sd8 & solid & wt \% \\
\hline Grain size $<0.063 \mathrm{~mm}$ & sd9 & solid & wt \% \\
\hline Silicon dioxide & $\mathrm{SiO} 2$ & solid & wt $\%$ \\
\hline Titanium dioxide & $\mathrm{TiO} 2$ & solid & wt \% \\
\hline Aluminum oxide & $\mathrm{Al} 2 \mathrm{O} 3$ & solid & wt \% \\
\hline Iron oxide & $\mathrm{Fe} 2 \mathrm{O} 3$ & solid & wt \% \\
\hline Manganese oxide & $\mathrm{MnO}$ & solid & wt \% \\
\hline Magnesium oxide & $\mathrm{MgO}$ & solid & wt \% \\
\hline Calcium oxide & $\mathrm{CaO}$ & solid & wt \% \\
\hline Sodium oxide & $\mathrm{Na} 2 \mathrm{O}$ & solid & wt \% \\
\hline Potassium oxide & $\mathrm{K} 2 \mathrm{O}$ & solid & wt \% \\
\hline Strontium & SrS & solid & $\mathrm{mg} / \mathrm{kg}$ \\
\hline Barium & $\mathrm{Ba}$ & solid & $\mathrm{mg} / \mathrm{kg}$ \\
\hline Surface area & S.A. & solid & $\mathrm{m}^{2} / \mathrm{g}$ \\
\hline
\end{tabular}


Table 8. Results for variable selection on strontium distribution coefficient values of surficial sediments using partial least squares and all possible variables [See table 7 for variable descriptions. SEC, standard error of calibration; $R$, correlation; REP, relative error of prediction]

\begin{tabular}{|c|c|c|c|c|c|c|c|c|c|}
\hline \multirow{3}{*}{$\begin{array}{l}\text { Number of } \\
\text { variables }\end{array}$} & \multicolumn{9}{|c|}{ Variable selection optimization criteria } \\
\hline & \multicolumn{3}{|c|}{ SEC } & \multicolumn{3}{|c|}{$\mathbf{R}$} & \multicolumn{3}{|c|}{ REP (percent) } \\
\hline & Variable & Value & Factor & Variable & Value & Factor & Variable & Value & Factor \\
\hline 1 & $\mathrm{MnO}$ & 3.182 & 1 & $\mathrm{MnO}$ & 0.709 & 1 & $\mathrm{sd} 3$ & 32.3 & 1 \\
\hline 2 & $+\mu S(\mathrm{eq})$ & 2.677 & 1 & $+\mu S(e q)$ & .805 & 1 & $+\mathrm{Mg}(\mathrm{c})$ & 26.7 & 2 \\
\hline 3 & $+\mathrm{pH}(\mathrm{eq})$ & 2.291 & 2 & $+\mathrm{pH}(\mathrm{eq})$ & .861 & 2 & + sd 9 & 23.7 & 2 \\
\hline 4 & $+\mathrm{S} . \mathrm{A}$ & 1.75 & 2 & + S.A. & .921 & 2 & + S.A. & 19.5 & 2 \\
\hline 5 & + sd3 & 1.593 & 3 & $+\mathrm{sd} 3$ & .936 & 3 & $+\mu \mathrm{S}(\mathrm{i})$ & 17.9 & 3 \\
\hline 6 & + T.C. & 1.487 & 3 & $+\mathrm{T} . \mathrm{C}$. & .944 & 3 & $+\mathrm{Na}(\mathrm{c})$ & 17.5 & 3 \\
\hline 7 & $+\mathrm{sd} 4$ & 1.423 & 3 & $+\mathrm{sd} 4$ & .949 & 3 & $+\mathrm{pH}(\mathrm{c})$ & 17.1 & 4 \\
\hline 8 & + sd 9 & 1.375 & 4 & $+s d 9$ & .949 & 4 & $+\mathrm{Ksp}$ & 14.3 & 5 \\
\hline 9 & $+\operatorname{Sr}(\mathrm{s}, \mathrm{c})$ & 1.250 & 4 & $+\operatorname{Sr}(s, c)$ & .957 & 4 & $+\operatorname{Sr}(\mathrm{s}, \mathrm{c})$ & 13.7 & 4 \\
\hline 10 & $+\mathrm{Sr}(\mathrm{s})$ & 1.263 & 4 & $+\operatorname{Sr}(s)$ & .961 & 4 & + T.C. & 11.9 & 5 \\
\hline
\end{tabular}


Table 9. Results for variable selection on strontium distribution coefficient values of surficial sediments using partial least squares and all variables except grainsize distribution

[See table 9 for variable descriptions. SEC, standard error of calibration; R, correlation; REP, relative error of prediction].

\begin{tabular}{|c|c|c|c|c|c|c|c|c|c|}
\hline \multirow{3}{*}{$\begin{array}{l}\text { Number of } \\
\text { variables }\end{array}$} & \multicolumn{9}{|c|}{ Variable selection optimization criteria } \\
\hline & \multicolumn{3}{|c|}{ SEC } & \multicolumn{3}{|c|}{$\mathbf{R}$} & \multicolumn{3}{|c|}{ REP (percent) } \\
\hline & Variable & Value & Factor & Variable & Value & Factor & Variable & Value & Factor \\
\hline 1 & $\mathrm{MnO}$ & 3.182 & 1 & $\mathrm{MnO}$ & 0.709 & 1 & S.A. & 34.6 & 1 \\
\hline 2 & $+\mu S(e q)$ & 2.677 & 1 & $+\mu S(e q)$ & 0.805 & 1 & $+\mathrm{MnO}$ & 30.9 & 1 \\
\hline 3 & $+\mathrm{pH}(\mathrm{eq})$ & 2.291 & 2 & $+\mathrm{pH}(\mathrm{eq})$ & 0.861 & 2 & $+\mu S(e q)$ & 24.8 & 2 \\
\hline 4 & + S.A. & 1.751 & 2 & + S.A. & 0.921 & 2 & $+\mathrm{pH}(\mathrm{eq})$ & 20.0 & 2 \\
\hline 5 & $+\mathrm{Mg}(\mathrm{c})$ & 1.607 & 3 & $+\mathrm{Mg}(\mathrm{c})$ & 0.934 & 3 & $+\mathrm{Mg}(\mathrm{c})$ & 18.3 & 2 \\
\hline 6 & $+K(e q)$ & 1.500 & 3 & $+\mathrm{K}(\mathrm{eq})$ & 0.943 & 3 & + Clay & 16.7 & 2 \\
\hline 7 & + Ksp & 1.506 & 3 & $+K s p$ & 0.942 & 3 & $+\mathrm{Na}(\mathrm{s})$ & 15.0 & 4 \\
\hline 8 & $+\mathrm{Fe}_{2} \mathrm{O}_{3}$ & 1.432 & 4 & $+\mathrm{Fe}_{2} \mathrm{O}_{3}$ & 0.948 & 4 & $+\mathrm{Fe}_{2} \mathrm{O}_{3}$ & 14.2 & 5 \\
\hline 9 & $+\mathrm{Al}_{2} \mathrm{O}_{3}$ & 1.185 & 7 & $+\mathrm{Al}_{2} \mathrm{O}_{3}$ & 0.965 & 7 & $+\mathrm{Ba}$ & 12.4 & 7 \\
\hline 10 & $+\operatorname{Sr}(\mathrm{c})$ & 1.116 & 7 & $+\operatorname{Sr}(\mathrm{s})$ & 0.969 & 7 & $+K(c)$ & 11.7 & 7 \\
\hline
\end{tabular}

